\title{
Reduction of Ripple in Bidirectional Dc-Dc Converter for Fuel Cell
}

\author{
S.A. Elankurisil and Dr.S.S.Dash
}

\begin{abstract}
This paper presents a reduction of ripple using $\pi$ filter and $\mathrm{c}$ filter in bidirectional isolated dc-dc - dc converter. A typical application for this converter is battery charging for electrical vehicles, telecommunication and speed control of dc-motor. The advantages of the half bridge circuit with $\mathrm{c}$ filter are reduced ripple content present in the voltage and current waveforms, soft switching, low cost and high efficiency. The use of fuel cells is now envisaged to supply electrical energy in high power rail transportation application. The mat lab simulation results are compared with the experimental results.
\end{abstract}

Index Terms-Soft switching, microcontrollers, bidirectional dc-dc converters, half bridge converters

\section{INTRODUCTION}

Isolated bidirectional dc-dc converters are widely used in UPS battery charging and discharging systems. For such fuel cell energy system application functions of this $\mathrm{dc}-\mathrm{dc}$ converter are two fold; first to boost the voltages for the filter motor drive [1]-[3].

This converter has the advantages of reduced ripple from $12 \mathrm{~V}$ battery derived power to boost the high voltage bus up to $252 \mathrm{~V}$ and second to store the content, reduced switching losses, improved EMI increased efficiency, High reliability and low cost. It is a good alternative to isolated boost full bridge dc-dc converter. The main objective is to reach high efficiency, high power density and cheap topology in a simple structure. Normally the voltage source converter has high current ripples, while a current source converter requires voltage clamp circuit [5]. This paper presents a bidirectional dc-dc converter. This converter is based on the dual half bridge with $\pi$ filter topology, Compared to the full bridge topologies, it has reduced component count for the same power rating with no total power rating penalty. Zero voltage switching is applied in all the switches without any additional component. This circuit allows efficient power conversion, easy control, light weight and compact packing.

Active clamping technique has been an attractive choice due to ZVS for both the main switch and auxiliary switch [6]-[8]. However, most of the existing soft switched dc $-\mathrm{dc}$ converters are lower bidirectional [9]-[13].

This paper presents a open loop half bridge bidirectional

Manuscript received june25, 2010(Submittedjune25,2010).

S.A.Elankurisil,ResearchScholar,SathyabamaUniversity,Chennai,India, e.mail:saelankurisil@gmail.com.phone:9442936797

Dr.S.S.Dash, Professor, SRM University, Chennai, India, email:munu_dash_2k@yahoo.com dc-dc converter with $\pi$ filter simulation model in mat lab 7.5 version. The above literature does not deal with comparison of $\pi$ filter and C- filter for the dc-dc converter. This work deals with reduction of ripple in bidirectional dc-dc converter

\section{CONVERTER DESCRIPTION AND ANALYSIS}

Fig 1 shows the half bridge bidirectional dc-dc converter. Fig 2 shows the soft switched bidirectional half bridge $\pi$ filter with dc-dc

Converter. It contains five parts including a dc input circuit, a primary side circuit, a secondary side circuits a filter circuit and a dc output circuit.

\section{$\stackrel{\text { Power flow }}{\longleftrightarrow}$}

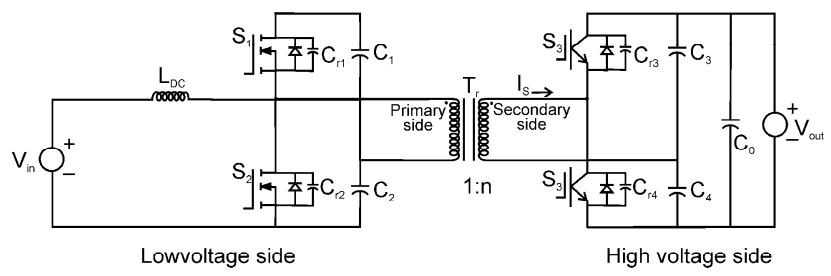

Fig 1- soft switched bidirectional half-bridge dc-dc convertor

The major symbol representation is summarized as follows; $\mathrm{V}_{\text {in }}$ and $\mathrm{L}_{\mathrm{dc}}$ are the input circuit parameters. They are input voltage and input inductor. Primary circuit has switches $\mathrm{S}_{1}, \mathrm{~S}_{2}, \mathrm{C}_{\mathrm{r} 1}, \mathrm{C}_{\mathrm{r} 2}, \mathrm{C}_{1}$ and $\mathrm{C}_{2}$. Secondary circuit has $\mathrm{S} 3$ and $\mathrm{S}_{4}$ switches $\mathrm{C}_{3}$ and $\mathrm{C}_{4}$ Filter circuit are $\mathrm{L}_{\mathrm{f}}$ filter inductor, $\mathrm{C}_{\mathrm{f} 1}$ and $\mathrm{C}_{\mathrm{f} 2}$ are filter capacitor. $\mathrm{C}_{0}$ and $\mathrm{V}_{0}$ are output capacitor and output voltage. The operation allows a resonant discharge of the lossless snubber capacitance of the switching devices and each devices antiparallel diode is conducted before the conduction of switching devices.

There are two modes

Mode: 1 Energy storing mode

Mode: 2 Energy transferring mode

\section{Energy storing mode :}

In the input side supply voltage is applied within the range of $12-15 \mathrm{v}$ with internal resistance of $1 \Omega$. Energy is stored in the Inductor. Stored energy is released after some time interval.Time period is depend upon the switching frequency.

\section{Energy transferring Mode:}

To transfer the energy from Inductor to the entire circuit. The duty cycle ratio is $50 \%$.

TABLE : 1 OUTPUT VOLTAGE WITH $\pi$ FILTER

\begin{tabular}{|l|l|l|l|l|}
\hline Factor 1 & Factor 2 & Factor 3 & Factor 4 & output \\
\hline
\end{tabular}




\begin{tabular}{|c|c|c|c|c|}
$\begin{array}{c}\text { A:Input } \\
\text { Voltage } \\
\text { volts }\end{array}$ & $\begin{array}{c}\text { B:Filter } \\
\text { Inductance } \\
\text { microhenry }\end{array}$ & $\begin{array}{c}\text { C:Filter } \\
\text { Capacitance } \\
\text { Micro } \\
\text { Farad }\end{array}$ & $\begin{array}{c}\text { D:Load } \\
\text { Resistance } \\
\text { Ohms }\end{array}$ & $\begin{array}{c}\text { voltage } \\
\text { in } \\
\text { volts }\end{array}$ \\
\hline 20 & 1 & 100 & 10 & 45.28 \\
\hline 20 & 2 & 90 & 20 & 54.02 \\
\hline 20 & 3 & 80 & 30 & 58.07 \\
\hline 20 & 4 & 70 & 40 & 60.39 \\
\hline 24 & 1 & 100 & 10 & 54.56 \\
\hline 24 & 2 & 90 & 20 & 65.08 \\
\hline 24 & 3 & 80 & 30 & 69.95 \\
\hline 24 & 4 & 70 & 40 & 72.75 \\
\hline 28 & 1 & 100 & 10 & 63.83 \\
\hline 28 & 2 & 90 & 20 & 76.13 \\
\hline 28 & 3 & 80 & 30 & 81.84 \\
\hline 28 & 4 & 70 & 40 & 85.11 \\
\hline 32 & 1 & 100 & 10 & 73.11 \\
\hline 32 & 2 & 90 & 20 & 87.19 \\
\hline 32 & 3 & 80 & 30 & 93.72 \\
\hline 32 & 4 & 70 & 40 & 97.47 \\
\hline & & & & \\
\hline
\end{tabular}

TABLE : 2 C FILTER

\begin{tabular}{|c|c|c|c|}
\hline Factor 1 & Factor 2 & Factor 3 & output \\
\hline $\begin{array}{c}\text { A:Input } \\
\text { Voltage } \\
\text { volts }\end{array}$ & $\begin{array}{c}\text { C:Filter } \\
\text { Capacitance } \\
\text { Micro } \\
\text { Farad } \\
\end{array}$ & $\begin{array}{c}\text { D:Load } \\
\text { Resistance } \\
\text { Ohms }\end{array}$ & $\begin{array}{c}\text { voltage } \\
\text { in } \\
\text { volts }\end{array}$ \\
\hline 20 & 100 & 10 & 44.28 \\
\hline 20 & 90 & 20 & 53.02 \\
\hline 20 & 80 & 30 & 57.07 \\
\hline 20 & 70 & 40 & 59.60 \\
\hline 24 & 100 & 10 & 53.54 \\
\hline 24 & 90 & 20 & 64.65 \\
\hline 24 & 80 & 30 & 68.69 \\
\hline 24 & 70 & 40 & 71.72 \\
\hline 28 & 100 & 10 & 62.63 \\
\hline 28 & 90 & 20 & 75.13 \\
\hline 28 & 80 & 30 & 80.84 \\
\hline 28 & 70 & 40 & 84.80 \\
\hline 32 & 100 & 10 & 72.21 \\
\hline 32 & 90 & 20 & 86.49 \\
\hline 32 & 80 & 30 & 92.93 \\
\hline 32 & 70 & 40 & 96.97 \\
\hline
\end{tabular}

From the Table 1 and Table 2 it can be seen that the $\pi$ filter is superior to the $\mathrm{C}$ filter. The two parameters are input voltage and filter inductance are more significant than other parameters.

\section{Mathematical ANALYSis OF CiRCUITS}

The section deals with calculation of DC - DC converter of ZVS-PWM. The calculation used to find out the output voltage control region of converters. The formula is utilized to be calculated the output voltage Losses:

1.The conduction losses in the rectifier are the same for conventional PWM and ZVS PWM.

$$
P_{\text {rect }}=4\left(I_{\text {out }} / 2 V_{\mathrm{f}}\right) \text {-------(1) }
$$

$\mathrm{V}_{\mathrm{f}}$ is the forward drop for the rectifier diodes, assuming that a full bridge rectifier is used.

2. The conduction losses on the primary bridge diodes are.

$$
\mathrm{P}_{\mathrm{D}}=\mathrm{V}_{\text {diode }} \mathrm{I}_{\mathrm{av}}
$$

$\mathrm{V}_{\text {diode }}$ is the forward voltage drop on the diodes and $\mathrm{I}_{\mathrm{av}}$ is the average current.

3. The conduction losses due to channel resistance of the switches can be calculated as

$\mathrm{P}_{\mathrm{Q}}=\mathrm{R}_{\mathrm{on}} \mathrm{I}_{\mathrm{rms}}$
To find parameters.
1. $\mathrm{L}=\mathrm{V}_{\mathrm{o}} \delta / \mathrm{f} \Delta \mathrm{I}$
2. $\mathrm{I}_{\mathrm{o}}=\mathrm{V}_{\mathrm{o}} / \mathrm{R}$
3. $\mathrm{P}_{\mathrm{o}}=\mathrm{V}_{\mathrm{o}}^{2} / \mathrm{R}$
4. $\mathrm{E}_{1}=4.44 \mathrm{~N}_{1} \Phi \mathrm{f}$
5. $\mathrm{E}_{2}=4.44 \mathrm{~N}_{2} \Phi \mathrm{f}$
6. $\mathrm{C}=\delta / 2 \mathrm{fR}$
7. $\mathrm{V}_{\mathrm{o}}=\mathrm{V}_{\text {in }} \delta$
8. $\mathrm{V}_{\mathrm{o}}=\frac{\mathrm{V}_{\text {in }}}{(1-\delta)}$

Total losses are $65 \mathrm{~W}$ approximately.

\section{Simulation Results}

The circuit model of boost converter is presented in the open loop with $\pi$ filter. The Fig 4(a )shows that open loop Boost mode circuit diagram with motor load Input voltage of 24 volts and produce higher voltage in the output.

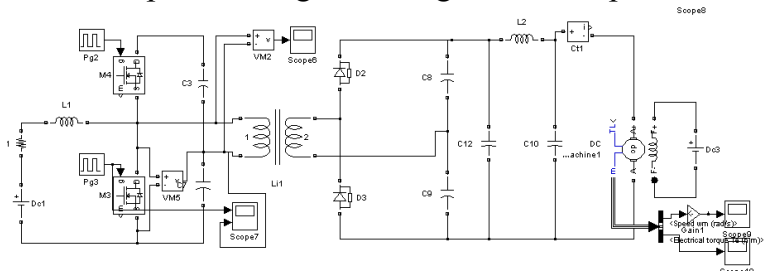

Fig 4(a) Boost Mode Circuit Diagram with $\quad \pi$ filter

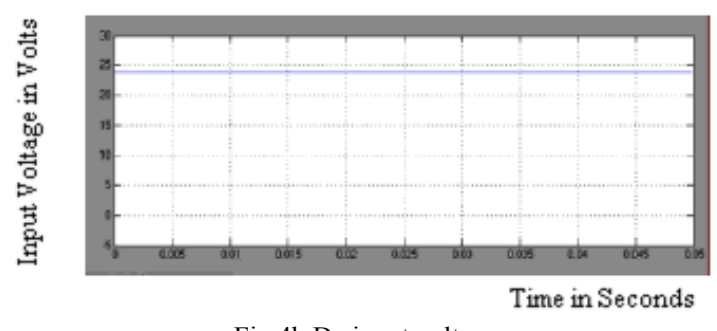

Fig 4b Dc input voltage

The input voltage is 24 volts as shown in Fig.4(b)

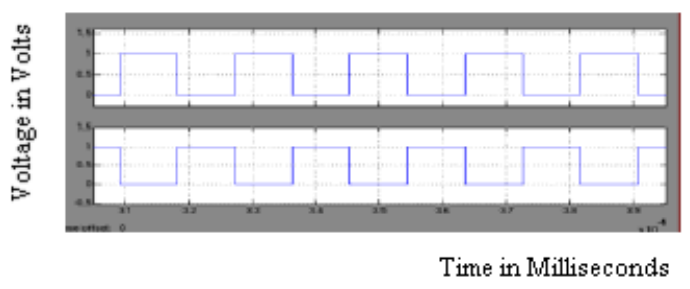

Fig 4(c) Driving pulses

The Driving pulses is applied to the switches are shown in Fig.4(c.) 


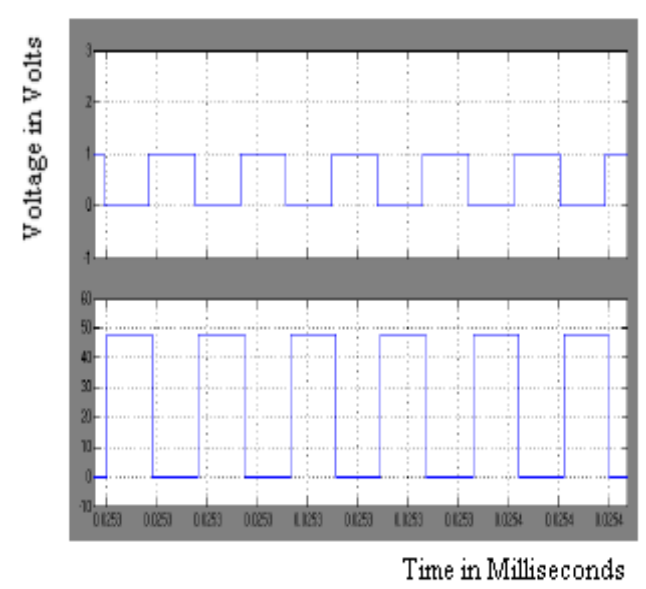

Fig 4(d) Switch-1 Vds and Vgs output

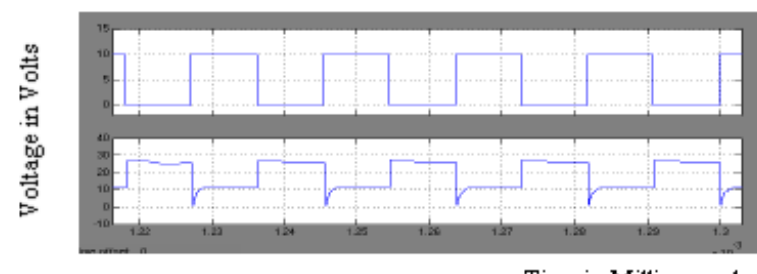

Fig 4e Switch-2 Vds and Vgs output

The switching output voltagaes across the drain to source and gate to source are shown in Fig 4(d) and 4(e)

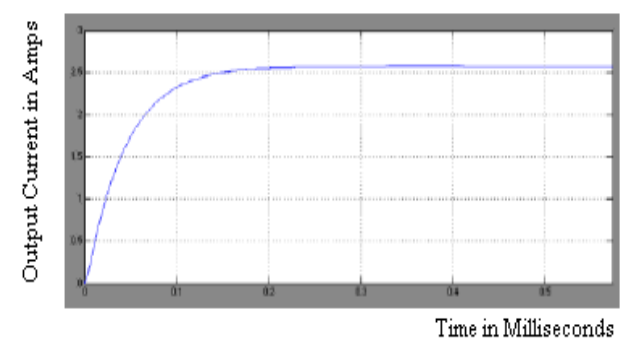

Fig. 4(f) DC output current

The output current flowing in the circuit is $2.5 \mathrm{~A}$ as shown in fig 4(f)

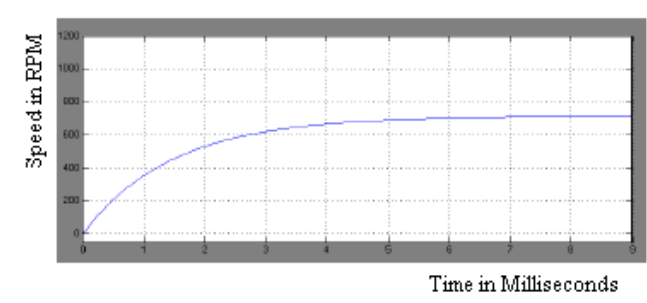

Fig 4(g) Armature speed

The motor runs at a speed of $700 \mathrm{rpm}$ at 48 volts in the miniature motor as shown in Fig.4(g)

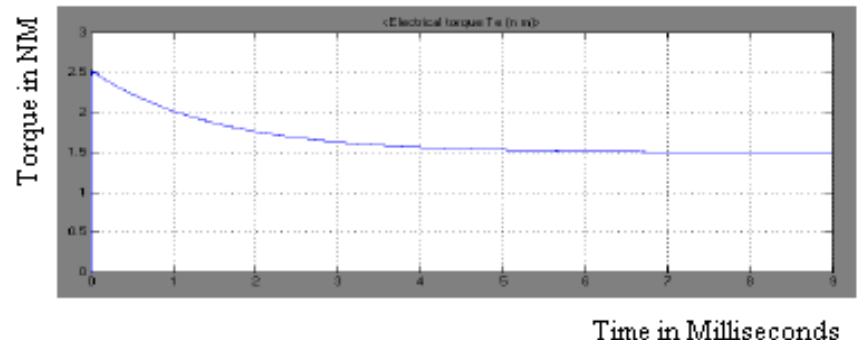

Fig 4(h) Torque

The Torque developed in the motor is $2.6 \mathrm{Nm}$ as shown in Fig.4(h)

TABLE: 3

\begin{tabular}{|c|c|}
\hline \multicolumn{2}{|c|}{ Circuit parameters } \\
\hline Input voltage & 24 volts \\
\hline Output voltage & 52 volts \\
\hline Load resistance & $100 \mathrm{Ohms}$ \\
\hline $\begin{array}{c}\text { Switching } \\
\text { frequency }\end{array}$ & $55 \mathrm{KHz}$ \\
\hline Filter capacitance & $70 \mu \mathrm{F}$ \\
\hline Miniature motor & 48 volts $1500 \mathrm{rpm}$ \\
\hline
\end{tabular}

TABLE: 4

\begin{tabular}{|c|c|c|}
\hline \multicolumn{3}{|c|}{ Ripple (Peak to Peak) } \\
\hline \multirow{2}{*}{$\begin{array}{c}\text { Voltag } \\
\text { e }\end{array}$} & $\pi$ filter & C filter \\
\cline { 2 - 3 } & 0.04 & 0.42 \\
\hline Current & 0.04 & 2 \\
\hline
\end{tabular}

The comparison of $\pi$ filter and $\mathrm{C}$ filter of voltage and current for the peak to peak ripple content are The comparison of $\pi$ filter and $\mathrm{C}$ filter of voltage and current for the peak to peak ripple content are presented in the table 4 . The power quality should be raised with the help of $\pi$ filter. Boost modecircuitwith c- filter Diagram is shown in fig 5(a ) The input voltage $24 \mathrm{Vis}$ applied is applied in the circuit diagram is shown in fig 5(b). The inverter output voltage is shown in fig5(c) The armature speed is similar speed of the $\pi$ filter is shown in fig5 (d).the torque is produced in the c-filter is shown in fig 5 (e). The combination of c-filter and $\pi$ filter of ripple voltage in peak to peak are shown in fig5(f) The combination of c-filter and $\pi$ filter of ripple current in peak to peak areshown in fig5(h)

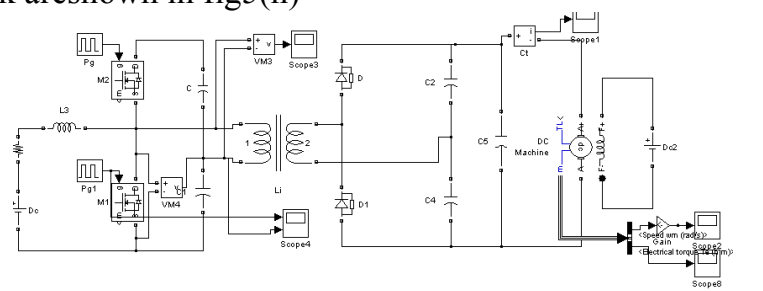

Fig 5(a) Boost Mode Circuit with c- filter Diagram

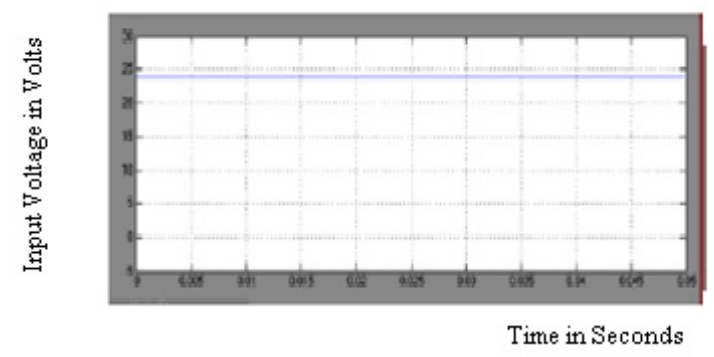

Fig 5(b) Dc input voltage 


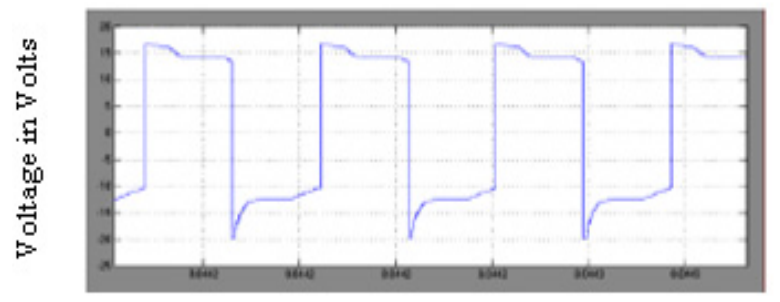

Time in Seconds

Fig 5(c) Inverter output

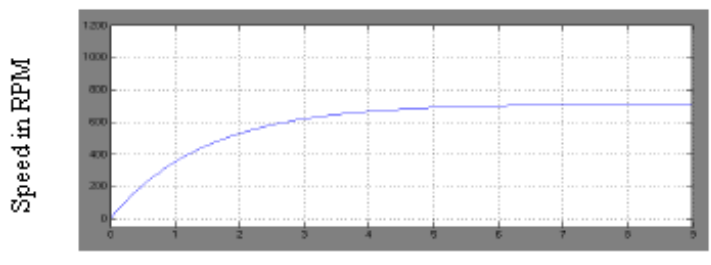

Time in Seconds

Fig 5(d) Armature speed

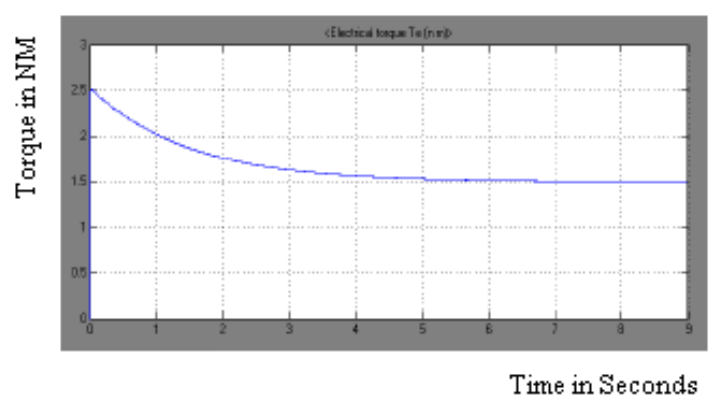

Fig 5(e) Torque

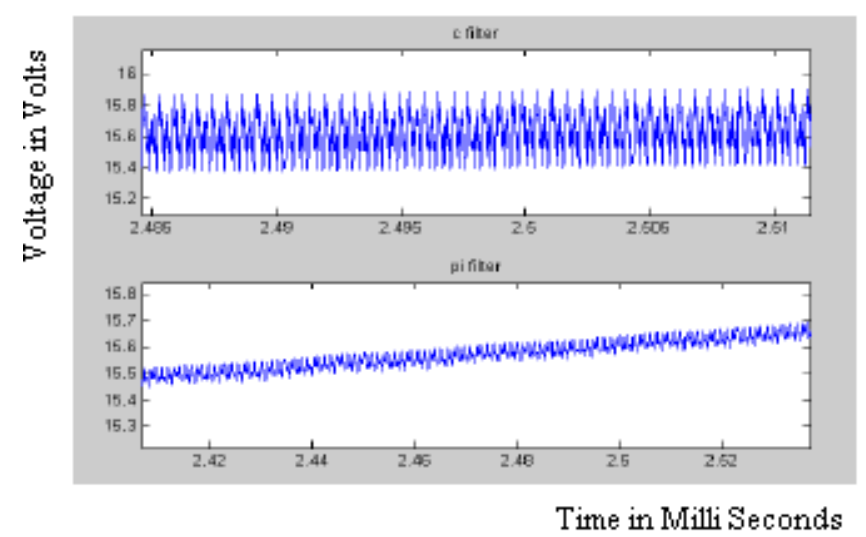

Fig 5(f) Ripple voltages of $\pi$ filter and C filter

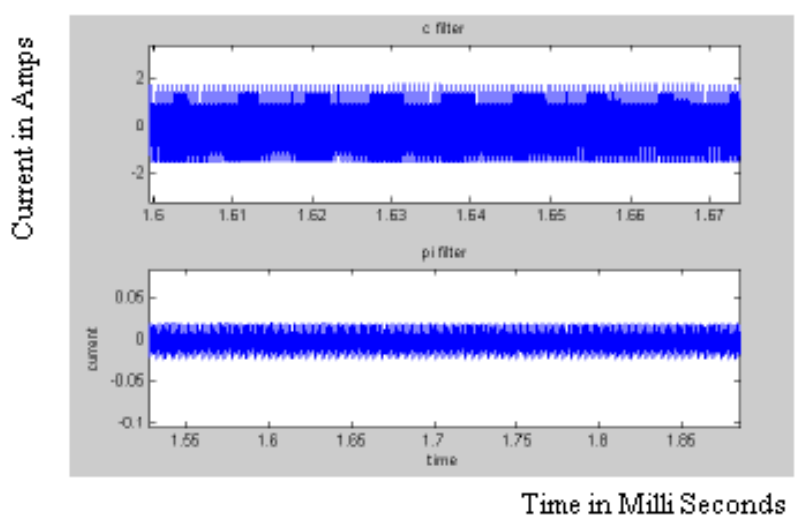

Fig 5(g) ripple current of $\pi$ filter and $C$ filter

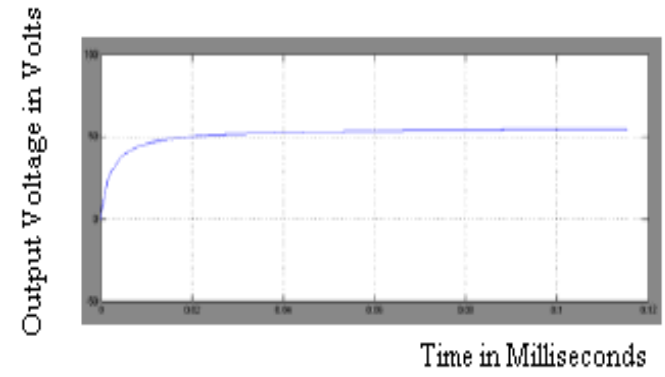

Fig 5(h) Boost Mode DC Output Voltage The boost mode c-filter

\section{EXPERIMENTAL VERIFICATION}

The hardware is fabricated and tested The AT89C2051 is a low-voltage, high-performance CMOS 8-bit microcomputer with2K Bytes of Flash programmable and erasable read only memory (PEROM). The device is manufactured using Atmel's high density nonvolatile memory technology and is compatible with the industry standard MCS-51 $1^{\mathrm{TM}}$ instruction set. By combining a versatile 8-bit CPU with Flash on a monolithic chip, the Atmel AT89C2051 is a powerful microcomputer which provides a highly flexible and cost effective solution to many embedded control applications $1 \mathrm{KW}$ laboratory model of bidirectional DC to DC converter is fabricated and tested in the laboratory. Driving pulses required by the MOSFET are generated using 89C51. They are amplified by using driver amplifier. Top view of the hardware is shown in fig 6(a). The input DC voltage as shown in fig 6(b). Driving pulses are shown in fig 6(c). The inverter output voltage is shown in fig 6(d). The boost output voltage as shown in fig $6(\mathrm{e})$. The buck output voltage of $15 \mathrm{v}$ is shown in fig $6(\mathrm{f})$. The converter has a full load efficiency of $94 \%$.

TABLE :5

\begin{tabular}{|c|c|}
\hline \multicolumn{2}{|c|}{ Circuit Parameters } \\
\hline M1-M4 & IRF530N \\
\hline LDC & $1.2 \mu \mathrm{H}$ \\
\hline $\mathrm{C} 1-\mathrm{C} 4$ & $3.2 \mathrm{nf}$ \\
\hline Transformer core & ETD 49 \\
\hline Transformer Ferrite grade & $3 \mathrm{C} 85$ \\
\hline $\mathrm{C}_{\mathrm{f}}$ & $14.7 \mu \mathrm{f}$ \\
\hline $\begin{array}{l}\text { Miniature motor 1A Model } 8 \\
19 \mathrm{~W}\end{array}$ & power \\
\hline
\end{tabular}




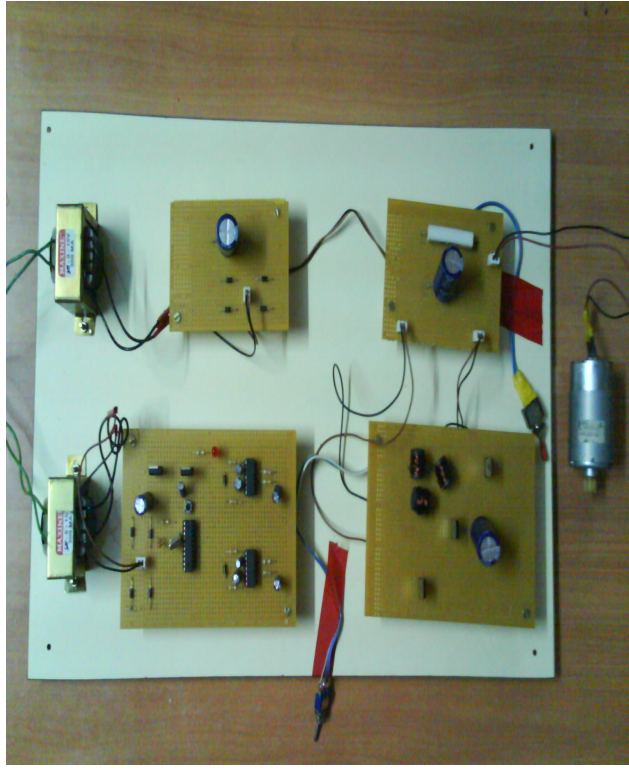

Fig. 6(a) Photo of the proto type

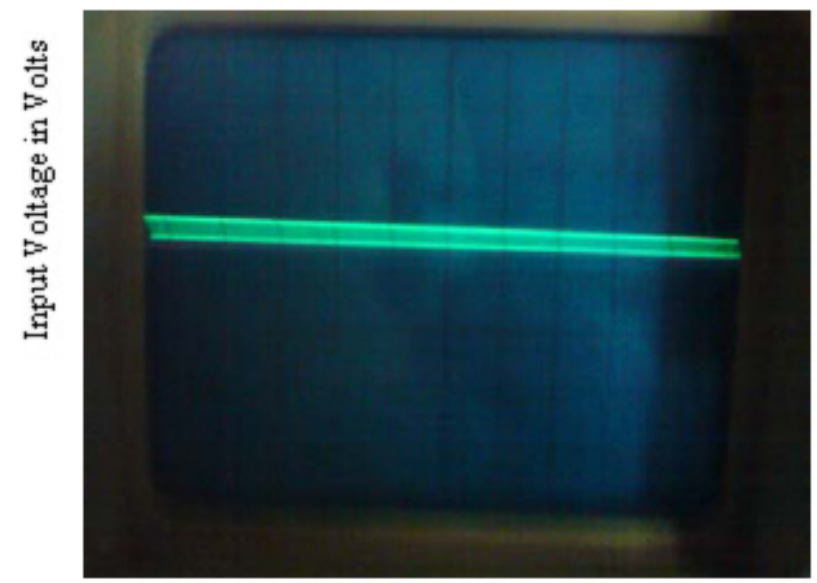

Time in Seconds

Fig. 6(b) DC input voltage

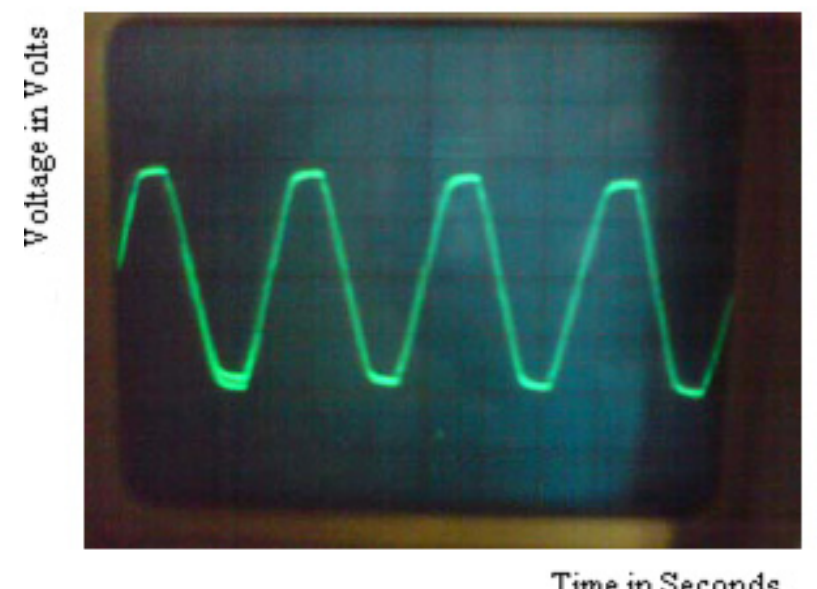

Fig. 6(c) AC input voltage

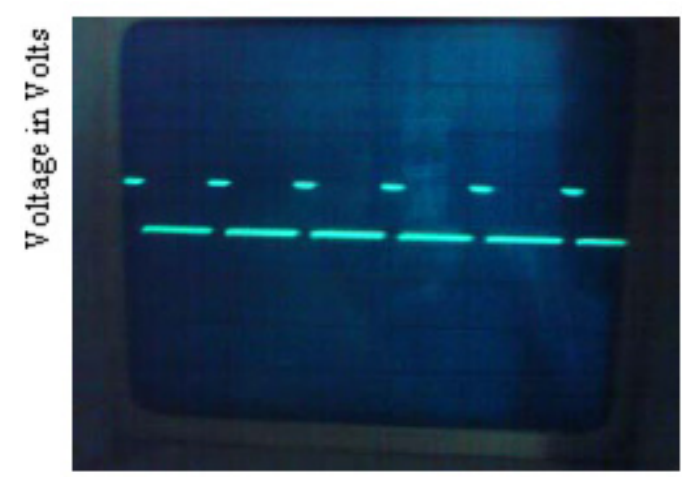

Time in Seconds

Fig. 6(d) Driving pulses

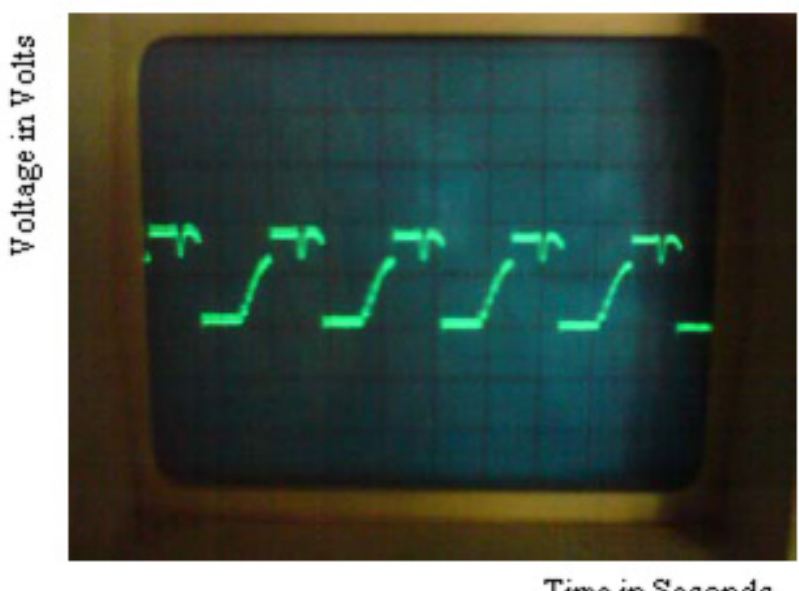

Fig. 6(e) Inverter output voltage

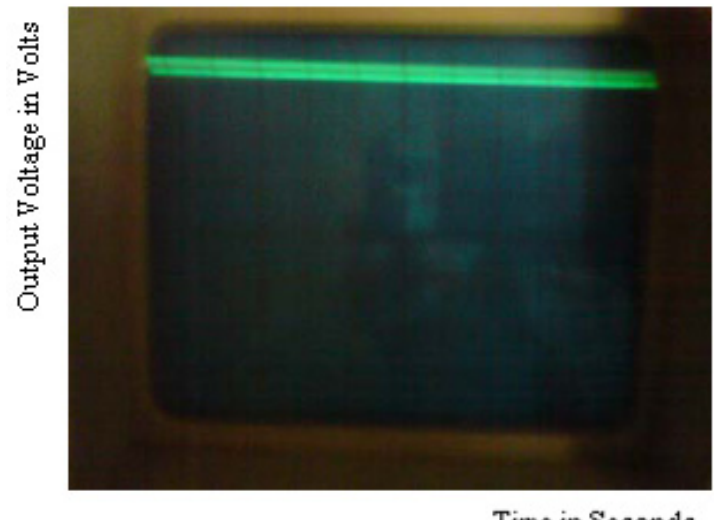

Fig. 6(f) Boost output voltage

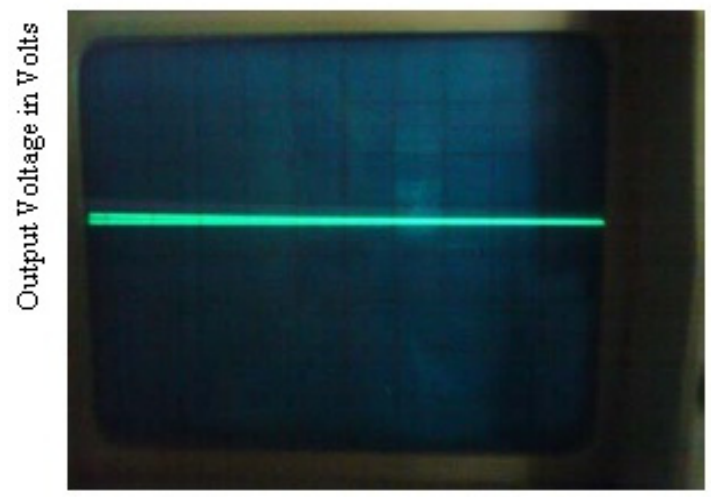

Time in Seconds 
Fig. 6(g) Buck output voltage

TABLE : 6 VARIATION OF EFFICIENCY

\begin{tabular}{|c|c|}
\hline output power(w & efficiency \\
\hline 420 & $88 \%$ \\
\hline 610 & $90 \%$ \\
\hline 800 & $91 \%$ \\
\hline 915 & $94 \%$ \\
\hline
\end{tabular}

\section{Output power Vs Efficiency}

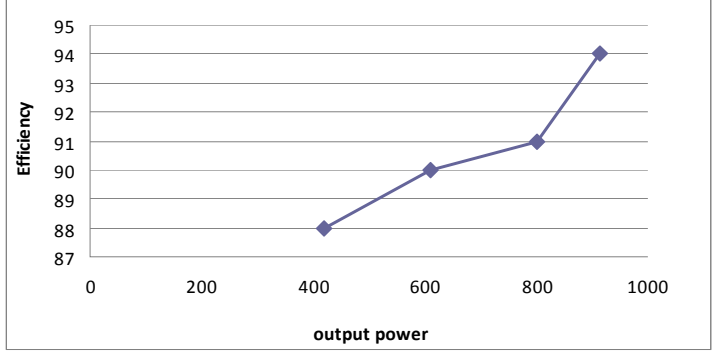

Fig. 6 (h) out put power Vs efficiency

\section{CONCLUSION}

The conventional half bridge bidirectional dc-dc converters have low power quality. $\pi$ filter reduces the ripple content and increases the efficiency. The input voltage and filter inductance are selected to reduce the harmonic content below $5 \%$. The efficiency is $94 \%$.. The experimental results closely agree with the simulation results.

\section{REFERENCES}

[1] HUI LI Fang z.peng, "A Natural zvs High power Bidirectional dc-dc converter with minimum number of drvices. IEEE transaction on Industrial applications Vol. 39, No. 2, March 2003.

[2] 2. S.caux, J.Lachaize, M.Fadel, "Modelling and control of a fuel cell system and storage elements in tansport applications. Journal of process control 15 (2005) 481-491.

[3] HUI LI, JANG Z-peng "Modelling of a new zvs bidirectional DC-DC converter IEEE transaction on aero space and electronic system Vol. 40, No. 1, Jan. 2004.

[4] HUI LI, Gui.Jia, "A New zvs bidirectional DC-DC converter for fuelcell and battery application. IEEE transaction on power electonics Vol.19 NO.1, Jan 2004.

[5] R. W. DeDonker and J. P. Lyons, "The auxiliary resonant commutated pole converter," in Proc. IEEE IAS Annu. Meeting Conf., 1990, pp. $1228-1235$.

[6] BO. Fang and Dehong XU, "I-KW PFC converter with compound active clamping" IEEE transactions on power electronics Vol.20 No.2 March 2005.

[7] C.M. DU Cunha Duarte and I. Barbi “ A New family of ZVS PWM active clamping dc to dc boost conerters Analysis, design and expeirmentation IEEE transpower electronics Vol.12 No.5 pp 824-831 Sep.1997.
[8] M.M. Jovanovid, "A tecnique for reducing rectifier reverse recovery related losses in high voltage high power boost converters in proc. APEC 97 Conf. 1997. PP 1000-1007

[9] Huang-Jen Chiu and Li-Weilin", A Bidirectional dc-dcconvertor for fuel cell Electric Vehicle driving system", IEEE transactions on power Electronics Vol.21 No.4, July 2006.

[10] P. Jose and N. Mohan A. Novel bidirectional dc-dc converter with ZVS and interleaving for dual voltagae systems in automobiles" in proc IEEE IAS 2002, pp 131-134.

[11] C.P. Henze HC Martin and D.W. Parsley "Zero voltage switching in high frequency power convertors using pulse width modulation" in proc IEEE APEC, 1988 pp 33-40.

[12] Rong-Jong wai and chung - you lin, "High voltage efficiency dc-dc converter with high voltage gain and reduced switch stress" IEEE transactions on Industrial Electronics Vol.54 No.1 February 2007.

[13] J. Y. Lee, G.W. Moon, and M. J. Youn, "Design of high-quality AC/DC converter with high-efficiency based on half-bridge topology," in Proc.IEEE PESC, June 1998, pp. 1054-1060.

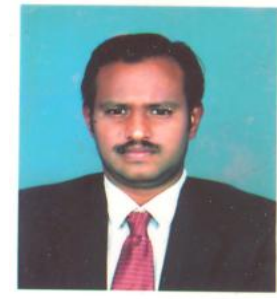

S.A.Elankurisil has obtained B.E degree from Madras university and M.E Degree from Sathyabama university in the years 1998 and 2006 respectively. He has 11 years of teaching experience. He is presently a research scholar at Sathyabama University. He is a life member of I.S.T.E.

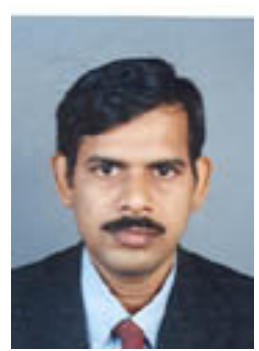

S.S.Dash is working as a Professor in SRM University, Chennai, India. He has 15 years of teaching and research experience. He has received ME Degree in power system engineering from University College of Engineering, Burla, India, in the year of 1996. He obtained $\mathrm{PhD}$ degree in Electrical Engineering from Anna University in the year of 2006. His current research interests concern FACTS, Drives, AI techniques, Power System Operation and Power Electronics converters. 


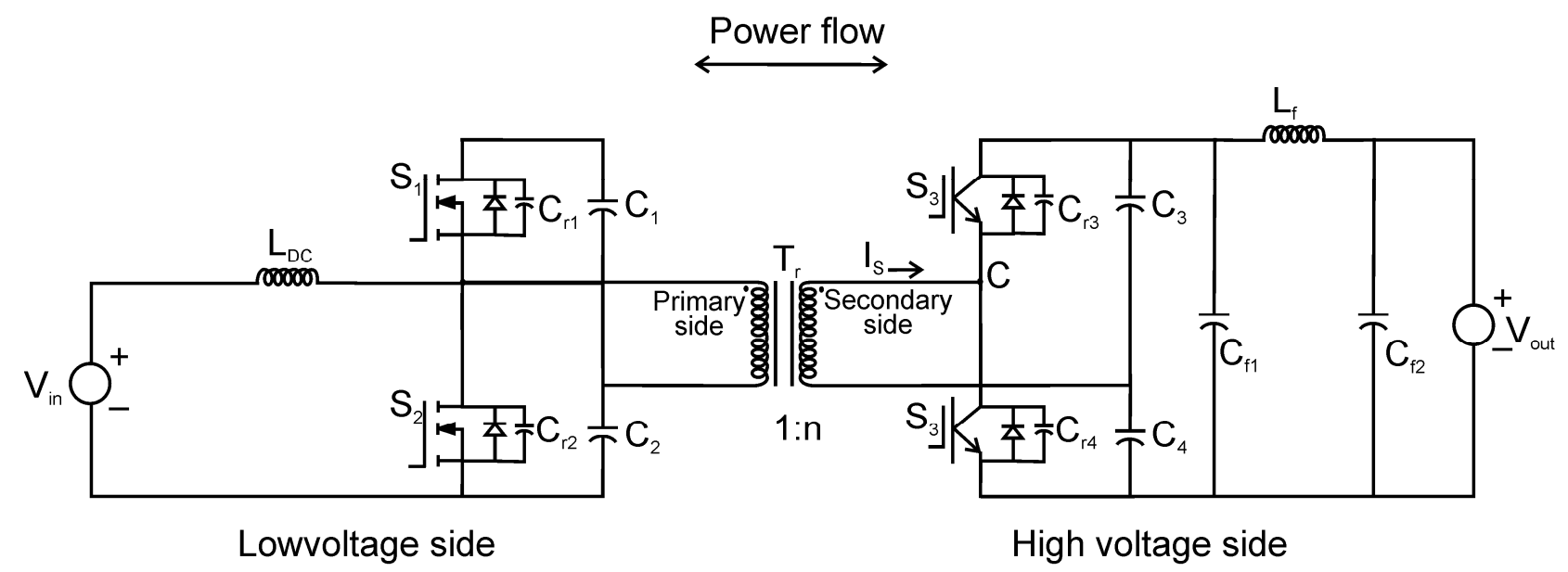

Fig 2 - soft switched bidirectional half-bridge pi filter with dc-dc convertor 